\section{Distribution of Ixodid Tick Species and Associated Risk Factors in Temporal Zones of Khyber Pakhtunkhwa Province, Pakistan}

\author{
Shahid Hussain Farooqi ${ }^{1, *}$, Muhammad Ijaz ${ }^{1}$, Muhammad Hassan Saleem ${ }^{1}$, \\ Muhammad Imran Rashid², Muhammad Oneeb ${ }^{2}$, Amjad Khan ${ }^{3}$, Amjad Islam Aqib ${ }^{1}$ \\ and Shakeel Mahmood ${ }^{4}$ \\ ${ }^{1}$ Department of Clinical Medicine and Surgery, University of Veterinary and Animal \\ Sciences, Lahore 54000 \\ ${ }^{2}$ Department of Parasitology, University of Veterinary and Animal Sciences, Lahore \\ 54000 \\ ${ }^{3}$ Department of Epidemiology and Public Health, University of Veterinary and \\ Animal Sciences, Lahore 54000 \\ ${ }^{4}$ Department of Geography, Government College University, Lahore 54000
}

\section{A B S T R A C T}

Distribution of various Ixodid tick species and risk factors associated with tick infestation and burden levels were studied in bovine from three distinct temporal zones of Khyber Pakhtunkhwa province of Pakistan. Twelve hundreds ticks were collected from four hundreds animals comprising of two hundred and fifty cattle and one hundred and fifty buffaloes. Descriptive statistics with Pearson's Chi-square test and regression model were applied to analyze the data. The results of study found Rhepicephalus the most prevalent genus followed by Heamaphysalis, Hyalomma, Dermacenter and Amblyomma with the prevalence of $78.50 \%, 10.33 \%, 10.08 \%, 0.67 \%$ and $0.42 \%$, respectively. On species basis, $R$. (Boophilus) annulatus, $R$. (Boophilus) microplus, Heamaphysalis aciculifer, $R$. appendiculatus, and $R$. decoloratus were noted $41.67,18.42,9.83,8.25$, and $6.83 \%$ respectively, whereas least prevalence was noted as $0.42 \%$ in case of $A$. pomposum and D. circumguttatus; $0.25 \%$ each was shown by D. rhinocerinus, Heam. Excavatum, and H. impeltatum; $0.17 \%$ exhibited by Heam. Houyi and R. distinctus; and $0.08 \%$ each displayed by Heam. Parmata, and H. egyptium, H. rufipes, R. longus and R. parvas. Risk factors analysis namely housing type, tick control, age and sex of animal presented significant $(\mathrm{P}<0.05)$ association with tick infestation and burden while type of breed showed significant association with tick infestation but was non-significant with tick burden. Topography presented inverse behavior to that of breed with tick burden and tick infestation. On the other hand, geo-location was only factor exhibiting non-significant ly associated $(\mathrm{P}>0.05)$ association with both dependent variables. The study concluded that Rhepicephalus was the most prevalent among the Ixodid genera whereas presumed risk factors were strongly associated with tick infestation and tick burden.

Article Information
Received 12 December 2016
Revised 26 March 2017
Accepted 12 May 2017
Available online 13 October 2017
Authors' Contribution
SHF, MI, MIR conceived and designed
the projecr and conducted research
work. MHS, AA, AIA arranged
and analyzed the data statistically.
SHF, AIA wrote and reviewed the
manuscript. SHF, SM arranged and
performed GIS Mapping.
Key words
Prevalence, Temporal Zones, Ticks,
Ixodid, Risk factors.

\section{INTRODUCTION}

G lobally ticks are transmitting comparatively wider range of pathogenic bacteria, protozoa, rickettsiae, spirochaets, and viruses, and are considered the most important vectors of livestock, humans, and companion animal diseases (Ghosh et al., 2007). These ticks carry different diseases like, protozoal i.e. babesiosis and theileriosis (Durrani and Kamal, 2008) and rickettsial; anaplasmosis (Kocan et al., 2004). Ticks can cause paralyses, toxicoses, allergic reactions and are vectors

\footnotetext{
Corresponding author: shahid.farooqivet@gmail.com 0030-9923/2017/0006-2011 \$ 9.00/0

Copyright 2017 Zoological Society of Pakistan
}

of a broad range of viral, rickettsial, bacterial and protozoan pathogens. The ticks identified in Pakistan from various livestock species are; Rhipicephalus sanguineus, Rhipicephalus (Boophilus) microplus, $R$ (B) annulatus, Hyalomma anatolicum anatolicum, $H$. isaacii, H. aegyptium, and Dermacentor marginatus (Kaiser and Hoogstraal, 1964). Ticks infestation is a somber issue of livestock in Khyber Pakhtunkhwa province of Pakistan (Perveen et al., 2010). The ticks genera reported in Punjab province of Pakistan includes; Hyalomma, Boophilus (now included in genus Rhipicephalus), Haemaphysalis and Rhipicephalus (Durrani and Kamal, 2008) with varying prevalence in different regions of the province. The variation in tick prevalence in different areas is attributed to a variety of factors like geo-climatic 
conditions, association and life style of different species of animals, awareness/education of the farmers and farm management practices (Ghosh et al., 2007). Besides these, Dermacentor (Ghosh et al., 2007) and Amblyomma (Ali et al., 2013) have also been reported. Over 20 ixodid tick species are often found on humans exposed to infested vegetation, four of these are Amblyomma spps, seven Dermacentor, three Haemaphysalis, two Hyalomma and six are Ixodes spps (Estrada and Jongejan, 1999). Till now there is insufficient data about Ixodid ticks in Khyber Pakhtunkhwa (KPK) province. Keeping in view the dire need of tick infestation estimation, the current study is an effort to identify various tick species and their distribution along with their associated risk factors in three distinct temporal zones of KPK.

\section{MATERIALS AND METHODS}

\section{Study area}

The study area included three temporal zones of province KPK i.e. district Buner, Mardan and Bannu. The temporal zones were selected based on climatic variation among the zones and districts densely populated with livestock were selected so as to make the data more reliable representative for the province. Temporal zone of district Buner lies between $34-9^{\circ}$ and $34-43^{\circ} \mathrm{N}$ latitude and $72-10^{\circ}$ and $72-47^{\circ} \mathrm{E}$ longitude with 44 to $-2^{\circ} \mathrm{C}$ temperature extremes, having average rainfall of approximately 762 $\mathrm{mm}$. District Mardan, the central zone, lies at $34^{\circ} 05^{\prime}$ to $34^{\circ}$ $32^{\prime}$ ' north latitudes and $71^{\prime \prime} 48^{\prime}$ to $72^{\circ} 25^{\prime}$ ' east longitudes with highest temperature climax of $46.5^{\circ} \mathrm{C}$ in June that falls to $0.5^{\circ} \mathrm{C}$ in January, whereas average annual rainfall goes to $559 \mathrm{~mm}$. District Bannu, southern zone, occupies $32.9861^{\circ}$ north and $70.6042^{\circ}$ east measuring $23.6{ }^{\circ} \mathrm{C}$ the average annual temperature with $327 \mathrm{~mm}$ of average rainfall. These zones have varying livestock populations and climatic variables.

\section{Study population and sampling method}

The ticks were collected from cattle and buffaloes during the months of June to September of year 2015. A total of 400 animals comprising of cattle $(n=250)$ and buffaloes $(n=150)$ inclusive of 100 tick free animals were studied. The total number of 1200 ticks ( $n=400$ ticks per zone) were collected from 300 animals ( $\mathrm{n}=100$ from each zone) by convenient sampling method. Additional 100 tick free animals were studied from the three regions to compare the association with possible risk factors $(n=34$ from Bannu, $n=33$ from Buner, $n=33$ from Mardan).

\section{Epidemiological survey}

The risk factors namely breed, sex of animal, housing system (wooden or concrete), different topographical locations, and exposure to acaricidals that had presumed association with tick infestation and tick burden were recorded using dichotomous questionnaire (Thrusfield, 2013). Age based categories of animals include bullocks/ cows (5-10 years), cattle young stock ( $3-5$ years), buffalo bullocks (5-10 years) and buffalo young stock (3-5 years). The cattle breeds as important risk factor were recorded as Sahiwal (B. indicus), Achai (B. indicus), Friesian (B. taurus), Jersey (B. taurus), cross-bred (Bos indicus $\times$ Bos taurus) while those of buffaloes (Bos bubalus babalis) were included in the names of Nili Ravi, Kundi and Azakheli.

\section{Ticks collection and storage}

Ticks were collected at dawn and dusk during June to September months of year 2015. Tick's burden was divided into three categories i.e. low, moderate and high burden groups. Animals having 1-25, 26-50 and >50 ticks were designated as low, moderate and high burden groups, respectively (Ali et al., 2013). Ticks were collected from various body regions of animals i.e. dewlap, axillary region and perineum of animals with the help of forceps. The collected tick's specimens were stored in labeled disposable containers having $70 \%$ ethanol solution to prevent shattering and to preserve their morphological features.

\section{Ticks identifications}

The collected ticks' samples preserved in $70 \%$ ethanol were carried to Entomology Laboratory, Department of Parasitology, University of Veteriniary and Animal Sciences, Lahore. Identification of ticks was performed using morphological keys mentioning genus identification (Taylor et al., 2007), and specie level identification (Keirans and Litwak, 1989; Yeoman et al., 1967).

\section{Statistical analysis}

Data regarding ticks' prevalence and associated risk factors were analyzed with descriptive statistics, Pearson's Chi-square test (Aqib et al., 2017) and regression model test using SPSS (statistical package for social sciences) version 20. Risk factors were associated with the tick burden at $P$ value $<0.05$ was considered significant.

\section{RESULTS}

The initial confirmatory correlation and later on applying the binary logistic regression model with particular Hosmer Lameshow goodness of fit test at 95\% confidence interval predicted $75 \%$ accuracy ability of the model. Moreover Hosmer and Lameshow test was found significantly fit for the current study at predictor value of 
1.00. The current study concluded $100 \%$ variance $\left(\mathrm{R}^{2}=\right.$ $1.00)$ in dependent variables i.e. tick infestation and tick burden. The Omnibus tests of model coefficients predicted highly significant $(\mathrm{P}<0.01)$ correlation with all variables except age and location (Table I).

The study found significant difference $(\mathrm{P}<0.05)$ in each temporal zones of KPK province of Pakistan on genera and species level while sex and developmental stages of ticks were non-significantly $(\mathrm{P}>0.05)$ differed (Table II). Among genera Rhepicephalus was significantly prevalent $(\mathrm{P}<0.05)$ in each zone of KPK province followed by Heamaphysalis, Hyalomma, Dermacente, and Amblyomma. Zone wise, Rhepicephalus was higher in Bannu, Heamaphysalis in Mardan, Hyalomma in Bannu, while Dermacenter and Amblyomma were found greater in number in Buner district of KPK province. Among the tick species, $R(B)$. annulatus was the most prevalent specie followed by $R(B)$. microplus and Heam. aciculifer were highly prevalent. Besides these, other ticks species identified include; R.appendiculatus, $R$. decoloratus, $H$. anatolicum, $H$. detritium, $H$. trancatum, $R$. evertsi, $R$. kochi, R. arnoldi, A. pomposum, D. circumguttatus, D. rhinocerinus, Heam. excavatum, H. impeltatum, Heam. houyi, R. distinctus, Heam. Parmata, H. egyptium, $H$. rufipes, $R$. longus and $R$. parvas. The data regarding sex of tick presented non-significant $(\mathrm{P}>0.05)$ results in all temporal zones. Similar pattern was observed when developmental stages of ticks were studied (Table II).

Table I.- Prevalence (\%) of Tick genera, species, sex and developmental stages in different temporal zones of KPK.

\begin{tabular}{|c|c|c|c|c|c|}
\hline Variables & & Northern Zone N (\%) & Central Zone N (\%) & Southern Zone N (\%) & P-value \\
\hline \multirow[t]{5}{*}{ Tick genera } & Rhepicephalus & $314(78.50)$ & $306(76.50)$ & $322(80.50)$ & $0.001 *$ \\
\hline & Heamaphysalis & $035(08.75)$ & $055(13.75)$ & $034(08.50)$ & \\
\hline & Hyalomma & $038(09.50)$ & $039(09.75)$ & $044 \quad(11.00)$ & \\
\hline & Dermacenter & $008(02.00)$ & $000(00.00)$ & $000(00.00)$ & \\
\hline & Amblyomma & $005(01.25)$ & $000(00.00)$ & $000(00.00)$ & \\
\hline \multirow[t]{23}{*}{ Tick species } & A. pomposum & $005(01.25)$ & $000(00.00)$ & $000(00.00)$ & $0.001 *$ \\
\hline & D. rhinocerinus & $003(0.750)$ & $000(00.00)$ & $000(00.00)$ & \\
\hline & D. circumguttatus & $005(01.25)$ & $000(00.00)$ & $000(00.00)$ & \\
\hline & Heam. Aciculifer & $030(07.50)$ & $055(13.75)$ & $033(08.25)$ & \\
\hline & Heam. Parmata & $001(0.250)$ & $000(00.00)$ & $000(00.00)$ & \\
\hline & Heam. Excavatum & $002(0.500)$ & $000(00.00)$ & $001(00.25)$ & \\
\hline & Heam. Houyi & $002(0.500)$ & $000(00.00)$ & $000(00.00)$ & \\
\hline & H. anatolicum & $023(05.75)$ & $020(05.00)$ & $012(03.00)$ & \\
\hline & H. trancatum & $000(00.00)$ & $000(00.00)$ & $028(07.00)$ & \\
\hline & H. detritium & $011(02.75)$ & $019(04.75)$ & $003(0.750)$ & \\
\hline & H. egyptium & $000(00.00)$ & $000(00.00)$ & $001(0.250)$ & \\
\hline & H. impeltatum & $003(0.750)$ & $000(00.00)$ & $000(00.00)$ & \\
\hline & H. rufipes & $001(0.250)$ & $000(00.00)$ & $000(00.00)$ & \\
\hline & R. annulatus & $184(46.00)$ & $159(39.75)$ & $157(39.25)$ & \\
\hline & R. evertsi & $005(01.25)$ & $009(02.25)$ & $008(02.00)$ & \\
\hline & R. microplus & $072(18.00)$ & $074(18.50)$ & $075(18.75)$ & \\
\hline & R. decoloratus & $041(10.25)$ & $024(06.00)$ & $017(04.25)$ & \\
\hline & $R$. distinctus & $002(0.500)$ & $000(00.00)$ & $000(00.00)$ & \\
\hline & R. arnoldi & $001(0.250)$ & $002(0.500)$ & $003(0.750)$ & \\
\hline & R.appendiculatus & $008(02.00)$ & $038(09.50)$ & $053(13.25)$ & \\
\hline & R. longus & $000(00.00)$ & $000(00.00)$ & $001(0.250)$ & \\
\hline & R. kochi & $000(00.00)$ & $000(00.00)$ & $008(02.00)$ & \\
\hline & R. parvas & $001(0.250)$ & $000(00.00)$ & $000(00.00)$ & \\
\hline \multirow[t]{2}{*}{ Sexes of ticks } & Male & $084(21.00)$ & $078(19.50)$ & $076(19.00)$ & 0.761 \\
\hline & Female & $316(79.00)$ & $322(80.50)$ & $324(81.00)$ & \\
\hline \multirow{2}{*}{$\begin{array}{l}\text { Developmen- } \\
\text { tal Stage }\end{array}$} & Nymph & $21(05.25)$ & $014(03.50)$ & $015(03.75)$ & 0.408 \\
\hline & Adult & $379(94.75)$ & $386(96.50)$ & $385(96.25)$ & \\
\hline
\end{tabular}


Table II.- Levene's test for between the subjects effects.

\begin{tabular}{|c|c|c|c|c|c|c|}
\hline Variable & Dependent variables & Type III sum of square & df & Mean square & $\mathbf{F}$ & P-value \\
\hline \multirow[t]{2}{*}{ Location } & Tick infestation & 0.001436 & 1 & 0.001436 & 0.020275 & 0.887 \\
\hline & Tick Burden on animal & 0.24071 & 1 & 0.24071 & 0.396622 & 0.529 \\
\hline \multirow[t]{2}{*}{ Housing } & Tick infestation & 2.507594 & 1 & 2.507594 & 35.41049 & 0.000 \\
\hline & Tick Burden on animal & 8.051092 & 1 & 8.051092 & 13.26591 & 0.000 \\
\hline \multirow[t]{2}{*}{ Tick control } & Tick infestation & 5.510485 & 1 & 5.510485 & 77.81523 & 0.000 \\
\hline & Tick Burden on animal & 17.41349 & 1 & 17.41349 & 28.69247 & 0.000 \\
\hline \multirow[t]{2}{*}{ Topography } & Tick infestation & 0.013589 & 1 & 0.013589 & 0.191891 & 0.662 \\
\hline & Tick Burden on animal & 2.537108 & 1 & 2.537108 & 4.180432 & 0.042 \\
\hline \multirow[t]{2}{*}{ Age } & Tick infestation & 1.969907 & 2 & 0.984954 & 13.90883 & 0.000 \\
\hline & Tick Burden on animal & 9.438127 & 2 & 4.719064 & 7.775674 & 0.000 \\
\hline \multirow[t]{2}{*}{ Breed } & Tick infestation & 3.249468 & 7 & 0.46421 & 6.555245 & 0.000 \\
\hline & Tick Burden on animal & 7.902172 & 7 & 1.128882 & 1.860076 & 0.075 \\
\hline \multirow[t]{2}{*}{ Specie } & Tick infestation & 0 & 0 & NA & NA & NA \\
\hline & Tick Burden on animal & 0 & 0 & NA & NA & NA \\
\hline \multirow[t]{2}{*}{ Sex } & Tick infestation & 0.737408 & 1 & 0.737408 & 10.41316 & 0.001 \\
\hline & Tick Burden on animal & 4.361623 & 1 & 4.361623 & 7.186713 & 0.008 \\
\hline
\end{tabular}

Table III.- Odd ratios of different factors responsible for tick infestation in large ruminants in KPK, Pakistan June to September in 2015.

\begin{tabular}{|c|c|c|c|c|c|c|}
\hline \multirow[t]{2}{*}{ Variables } & \multirow[t]{2}{*}{ B } & \multirow[t]{2}{*}{ S.E } & \multirow[t]{2}{*}{ Sig } & \multirow[t]{2}{*}{$\begin{array}{c}\text { Exp } \\
\text { (B) }\end{array}$} & \multicolumn{2}{|c|}{$\begin{array}{l}95.0 \% \text { C.I. for } \\
\operatorname{Exp}(\text { B) }\end{array}$} \\
\hline & & & & & Lower & Upper \\
\hline Location & 0.137 & $1.450 \mathrm{E} 3$ & 0.809 & 1.147 & 0.960 & 1.46 \\
\hline Species & -1.346 & $5.090 \mathrm{E} 3$ & 0.000 & 0.260 & 0.031 & 0.45 \\
\hline Breed & 68 & 998.697 & 0.000 & 1.183 & 60 & 1.92 \\
\hline Age & -0.043 & $1.454 \mathrm{E} 3$ & 0.664 & 0.958 & 0.614 & 1.32 \\
\hline Sex & 0.120 & $2.487 \mathrm{E} 3$ & 0.000 & 1.127 & 0.831 & 1.41 \\
\hline Housing & -0.956 & $2.439 \mathrm{E} 3$ & 0.000 & 0.384 & 0.051 & 0.67 \\
\hline Tick control & 0.574 & $2.327 \mathrm{E} 3$ & 0.000 & 1.776 & 1.134 & 2.75 \\
\hline Topography & 0.485 & $2.718 \mathrm{E} 3$ & 0.001 & 1.623 & 1.113 & 2.68 \\
\hline
\end{tabular}

The "Levene's test for between subject effects" was applied on collected information regarding presumed risk factors like; housing type, tick control, age and sex of animal, which showed significant association $(\mathrm{P}<0.05)$ with both tick infestation and burden. The data regarding breeds was found significantly $(\mathrm{P}<0.05)$ associated with tick infestation but with tick burden it was noted nonsignificant $(\mathrm{P}>0.05)$. The topography was noted vice versa of breed's pattern of association with tick burden and infestation in that tick infestation was non-significantly associated $(\mathrm{P}>$.0.05) whereas tick burden was significantly $(\mathrm{P}<0.05)$ associated with topography. Apart from all only the geo-location was not found risk factor in occurrence of tick infestation (Table III).

\section{DISCUSSION}

The higher prevalence of Rhepicephalus and Heamaphysalis i.e. 78.5 and $10.33 \%$, respectively, are in line with the finding of Islam et al. (2006) who reported Rhepicephalus (Boophilus) the most predominant genus followed by Heamaphysalis in three distinct topographic zones of Bangladesh, viz. flood plains, hills and steppe 'Barind'. The justification of higher prevalence of above stated genera was correlated with high to moderate rainfall as quoted by Islam et al. (2006) coincides with current study. The higher tick intensity is also justifiable with progressing rainy season that make ticks' propagation suitable because of warm and humid environment (Lima et al., 2000). The decreasing pattern of prevalence of Hyalomma in current study was associated with rainy to semi-arid characteristics of temporal zones which is supported by Islam et al. (2006) and Harwood and James (1979).

Some of livestock associated ticks genera like Hyalomma, Rhipicephalus and Amblyomma were reported in previous study conducted by Muhammad et al. (2008). However five genera, Rhepicephalus, Hyalomma, Heamaphysalus, dermacenter and Amblyomma, identified in this project were also reported in neighbor countries like India and Bangladesh (Ghosh et al., 2007). Not to this only, Turkey was also reporting Ixodes, Haemaphysalis, Hyalomma, Dermacentor, and Rhipicephalus as major ticks' genera (Aydin and Bakirci, 2007). These genera are reported as found wide spread in the Anatolia region of turkey. The suitable hosts for these vectors and their resultant maladies are reported to be cattle, sheep, horses 
and dogs. The reason for the presence of these genera in Pakistan can be attributed to the practice of mixed animal's species rearing in majority of animals facilities over the country. The prevalence rates vary between Turkey and Pakistan, which might be due to the variations in the climatic dynamics between the two regions. Climatic conditions dictate the dynamics of ticks and tick-borne diseases by influencing the distribution of ticks and their seasonal occurrence. Steadfast foretelling models are required to determine the direct effect of climatic shift on the burden of ticks and tick-borne diseases. The bioecology of TBDs is complicated, as is the impact of climate on spatial and regional variability in ticks and tick-borne diseases. The comparative impact of climate is frequently difficult to discriminate from variability in other determinants that are not directly climatic. Climate variations may influence not only tick biology but also indirectly affects the host ecology and abundance, causing appearance of TBDs in some regions and their disappearance in other areas (Ahmed et al., 2007). The data on tick distribution in Pakistan compared to other countries is still scarce.

The tempral zones of KPK province of Pakistan exhibited non-significant difference with tick burden and tick infestation which is contradicted to the studies conducted in other provinces of Pakistan (Durrani and Kamal, 2008; Khan et al., 1993; Sajid et al., 2008). The justification of this contraindication might be the fact of free movement of animals across the districts, higher number of small herds with unawareness of tick control measure, and mixed species rearing in KPK that makes no significant difference of tick infestation and burden among the temporal zones.

The significant association of housing type i.e. wooden and concrete type with tick infestation and burden of current study is line with the findings of Muhammad et al. (2008) and Chhabra (1992). The significant association is attributed to cracks and crevices present in wooden houses that provide hiding space for the ticks. Tick control measure was also important risk factor that presented predominant association coinciding with results of Shimizu et al. (2000) stating application of acaricides against theileriosis on animal body a good practice in its control.

A non-significant correlation of topography with tick burden whereas its significant association with tick infestation was also supported by findings of Kumsa et al. (2012), Fourie and Kok (1992) and Heath et al. (1977). The higher tick burden is justifiable with movement of infested animals from highlands to low lands that supports tick propagation. The higher tick infestation and burden in cattle significantly differing to that of buffaloes is attributed to thin hairy coat of cattle that makes cattle more prone to tick infestation (Sajid et al., 2009). Higher tick infestation in exotic breeds and crossbreds compared to indigenous breeds, within specie, was also reported by L'Hostis et al. (2006) and Atif et al. (2012). Wambura et al. (1998) have also reported higher tick resistance in $B$. indicus than $B$. taurus and their crosses. This resistance pattern was explained by higher serum complements in indigenous breeds (Sajid et al., 2009). The inherited traits in $B$. indicus also explain resistance in indigenous breeds (Jongejan and Uilenberg, 2004).

The higher susceptibility of older animals (7-9 year), followed by younger (1-3year), and young adult age (4-6year) to tick infestation and burden resembled to findings of studies carried out by Manan et al. (2007), Vatsya et al. (2007) and Kabir et al. (2011). The buildup of immunity by repeated exposure in adult animals explains less infestation compared to younger animals. Kabir et al. (2011) reported young cattle to be 2.23 times more susceptible to tick infestation than adult cattle in Pakistan. Higher susceptibility of older animals to tick infestation and burden is explainable by poor body conditions which directly affect the immune status of the animals. Similar justification has been reported by Rony et al. (2010).

The current study reported tick infestation and burden form external body along with risk factors that will be extended to gut and blood specimens to identify the ticks in next study.

\section{ACKNOWLEDGMENT}

The Author is grateful to Higher Education Commission (HEC), Pakistan, for funding the current project. The author also appreciates the humble cooperation from Department of Parasitology, University of veterinary and Animal Sciences, Lahore.

Statement of conflict of interest

Authors have declared no conflict of interest.

\section{REFERENCES}

Ahmed, J., Alp, H., Aksin, M. and Seitzer, U., 2007. Current status of ticks in Asia. Parasitol. Res., 101: 159-162. https://doi.org/10.1007/s00436-0070696-3

Ali, Z., Maqbool, A., Muhammad, K., Khan, M. and Younis, M., 2013. Prevalence of Theileria annulata infected hard ticks of cattle and buffalo in Punjab, Pakistan. J. Anim. Pl. Sci., 23: 20-26.

Atif, F., Khan, M., Iqbal, H., Ali, Z. and Ullah, S., 2012. Prevalence of cattle tick infestation in three districts 
of the Punjab, Pakistan. Pakistan J. Sci., 64: 49-53

Aqib, I.A., Ijaz, M., Durrani, M.Z., Anjum, A.A., Hussain, R., Sana, S., Farooqi, S.H., Hussain, K. and Ahmad, S.S., 2017. Prevalence and antibiogram of Staphylococcus aureus, a camel mastitogen from Pakistan. Pakistan J. Zool., 49: 861-867.

Aydin, L. and Bakirci, S., 2007. Geographical distribution of ticks in Turkey. Parasitol. Res., 101: 163-166. https://doi.org/10.1007/s00436-0070694-5

Chhabra, M., 1992. Tick infestations of livestock in India and their control. Int. J. trop. Insect Sci., 13: 649655. https://doi.org/10.1017/S1742758400016258

Durrani, A. and Kamal, N., 2008. Identification of ticks and detection of blood protozoa in friesian cattle by polmerase chain reacton test and estimation of blood parameters in district Kasur, Pakistan. Trop. Anim. Hlth. Prod., 40: 441-447. https://doi. org/10.1007/s11250-007-9117-y

Estrada-Peña, A. and Jongejan, F., 1999. Ticks feeding on humans: A review of records on human-biting Ixodoidea with special reference to pathogen transmission. Exp. appl. Acarol., 23: 685-715. https://doi.org/10.1023/A:1006241108739

Fourie, L. and Kok, O., 1992. The role of host behavior in tick-host interactions: A domestic host-paralysis tick model. Exp. appl. Acarol., 13: 213-225. https:// doi.org/10.1007/BF01194937

Ghosh, S., Bansal, G.C., Gupta, S.C., Ray, D., Khan, M.Q., Irshad, H., Shahiduzzaman, M., Seitzer, U. and Ahmed, J.S., 2007. Status of tick distribution in Bangladesh, India and Pakistan. Parasitol. Res., 101: 207-216. https://doi.org/10.1007/s00436-0070684-7

Harwood, R.F. and James, M.T., 1979. Entomology in human and animal health. Bailliere Tindall.

Heath, A., Pearce, D.M., Tenquist, J. and Cole, D., 1977. Some effects of a tick infestation (Haemaphysalis longicornis) on sheep. N. Z. J. agric. Res., 20: 1922. https://doi.org/10.1080/00288233.1977.104272 96

Islam, M.K., Alim, M.A., Tsuji, N. and Mondal, M.M.H., 2006. An investigation into the distribution, hostpreference and population density of Ixodid ticks affecting domestic animals in Bangladesh. Trop. Anim. Hlth. Prod., 38: 485-490. https://doi. org/10.1007/s11250-006-4381-9

Jongejan, F. and Uilenberg, G., 2004. The global importance of ticks. Parasitology, 129: S3-S14. https://doi.org/10.1017/S0031182004005967

Kabir, M., Mondal, M., Eliyas, M., Mannan, M., Hashem, M., Debnath, N., Miazi, O., Mohiuddin, C., Kashem,
M. and Islam, M., 2011. An epidemiological survey on investigation of tick infestation in cattle at Chittagong District, Bangladesh. Afr. J. Microbiol. Res., 5: 346-352.

Kaiser, M. and Hoogstraal, H., 1964. The Hyalomma ticks (Ixodoidea, Ixodidae) of Pakistan, India, and Ceylon, with keys to subgenera and species. Acarologia, 6: 257-286.

Keirans, J.E. and Litwak, T.R., 1989. Pictorial key to the adults of hard ticks, family Ixodidae (Ixodida: Ixodoidea), east of the Mississippi River. $J$. med. Ent., 26: 435-448. https://doi.org/10.1093/ jmedent/26.5.435

Khan, M., Hayar, C., Iqbal, Z. and Hayat, B., 1993. Prevalence of ticks on livestock in Faisalabad (Pakistan). Pakistan Vet. J., 13: 182-182.

Kocan, K., de La Fuente, J., Blouin, E. and GarciaGarcia, J., 2004. Anaplasma marginale (Rickettsiales: Anaplasmataceae): recent advances in defining host-pathogen adaptations of a tickborne rickettsia. Parasitology, 129: S285-S300. https://doi.org/10.1017/S0031182003004700

Kumsa, B., Tamrat, H., Tadesse, G., Aklilu, N. and Cassini, R., 2012. Prevalence and species composition of ixodid ticks infesting horses in three agroecologies in central Oromia, Ethiopia. Trop. Anim. Hlth. Prod., 44: 11. https://doi.org/10.1007/ s11250-011-9897-y

L'Hostis, M., Bureaud, A. and Gorenflot, A., 1996. Female Ixodes ricinus (Acari, Ixodidae) in cattle of western France: Infestation level and seasonality. Vet. Res., 27: 589-598.

Lima, W., Ribeiro, M. and Guimaraes, M., 2000. Seasonal variation of Boophilus microplus (Canestrini, 1887) (Acari: Ixodidae) in cattle in Minas Gerais State, Brazil. Trop. Anim. Hlth. Prod., 32: 375-380. https://doi.org/10.1023/A:1005229602422

Manan, A., Khan, Z., Ahmad, B. and Abdullah, 2007. Prevalence and identification of ixodid tick genera in frontier region Peshawar. J. agric. boil. Sci., 2: 1.

Muhammad, G., Naureen, A., Firyal, S. and Saqib, M., 2008. Tick control strategies in dairy production medicine. Pakistan Vet. J., 28: 43.

Farzana, P., Bilqees, F.M., Habib, A., Bibi, N.S. and Hussain, F.M.., 2010. Frequency of ixodid ticks infestation in livestock in two districts of NWFP, Pakistan. Proc. Parasitol., 49: 127-141.

Rony, S., Mondal, M., Begum, N., Islam, M. and Affroze, S., 2010. Epidemiology of ectoparasitic infestations in cattle at Bhawal forest area, Gazipur. Bangladesh J. Vet. Med., 8: 27-33.

Sajid, M., Iqbal, Z., Khan, M. and Muhammad, G., 2008. 
Point prevalence of hard ticks (Ixodids) infesting domestic ruminants of lower Punjab, Pakistan. Int. J. Agric. Biol., 10: 349-351.

Sajid, M.S., Iqbal, Z., Khan, M.N., Muhammad, G. and Khan, M.K., 2009. Prevalence and associated risk factors for bovine tick infestation in two districts of lower Punjab, Pakistan. Preven. Vet. Med., 92: 386-391. https://doi.org/10.1016/j. prevetmed.2009.09.001

Shimizu, S., Nojiri, K., Matsunaga, N., Yamane, I. and Minami, T., 2000. Reduction in tick numbers (Haemaphysalis longicornis), mortality and incidence of Theileria sergenti infection in fieldgrazed calves treated with flumethrin pour-on. Vet. Parasitol., 92: 129-138. https://doi.org/10.1016/ S0304-4017(00)00278-8

Taylor, M., Coop, R. and Wall, R., 2007. Parasites of cattle. Vet. Parasitol., 3: 51-151.

Thrusfield, M., 2013. Veterinary epidemiology. Elsevier. Vatsya, S., Yadav, C., Kumar, R.R. and Garg, R., 2007. Seasonal activity of Boophilus microplus on large ruminants at an organised livestock farm. J. Vet. Parasitol., 21: 125-128.

Wambura, P., Gwakisa, P., Silayo, R. and Rugaimukamu, E., 1998. Breed-associated resistance to tick infestation in Bos indicus and their crosses with Bos taurus. Vet. Parasitol., 77: 63-70. https://doi. org/10.1016/S0304-4017(97)00229-X

Yeoman, G.H., Walker, J.B., Ross, J. and Docker, T., 1967. The ixodid ticks of Tanzania. A study of the zoogeography of the Ixodidae of an East African country. Commonwealth Institute of Entomology, https://www.cabdirect.org/cabdirect/ abstract/19682900468 